\title{
Growth, yield attributes, yield and economics of winter popcorn (Zea mays everta Sturt.) as influenced by planting time fertility level and plant population under late sown condition
}

\author{
S. K. Singh ${ }^{1 *}$, R. N. Singh ${ }^{2}$ U. S. Ram $^{3}$ and M. K. Singh \\ Department of Agronomy, Institute of Agricultural Sciences, BHU, Varanasi- 221005 (Uttar Pradesh), INDIA \\ Krishi Vigyan Kendra ,Pampoli - 790102 (Arunachal Pradesh), INDIA \\ *Corresponding Author. E-mail: rupanksha.231302@gmail.com
}

Received: September 29, 2015; Revised received: May 24, 2016; Accepted: August 02, 2016

\begin{abstract}
The field experiment was laid out in split plot design with three replications, assigning in 27 treatment combinations i.e. three sowing dates of Pop corn (Zea mays everta Sturt.)cv. V.L. Amber (15 Dec, 30 Dec and 15 Jan) arranged in main plots and three level of plant population $\left(60000,80000\right.$ and 100,000 plants ha $\left.{ }^{-1}\right)$ in sub plot. Three level of fertility $\left(100: 50: 50,150: 65: 65\right.$ and 200:85:85 kg of N: $\mathrm{P}_{2} \mathrm{O}_{5}: \mathrm{K}_{2} \mathrm{O}$ ha $\left.{ }^{-1}\right)$ apportioned in sub-sub plots at the Research farm, Institute of Agricultural Sciences, BHU, Varanasi (U.P.) during late winter (rabi) seasons of 2009-10 and 201011 to study the influenced of planting time, fertility level and plant population on yield attributes, grain yield and economics of winter popcorn (Zea mays everta Sturt.) under late sown condition. The popcorn sown on $15^{\text {th }}$ December recorded highest plant height, leaf-area index, dry matter, popcorn growth rate, yield attributes and yield of pop corn were significantly $(P<0.05)$ affected and recorded highest benefit cost ratio $(3.78)$. While, the maintenance of 80,000 popcorn plants/ha proved optimum for pop corn as it significantly $(P<0.05)$ recorded highest number of kernel cob ${ }^{-1}$, grain yield $(32.61 \mathrm{q} / \mathrm{ha})$ and shelling percentage against density of 60,000 plants, while remained at par in straw yield over 100,000 plants. Application of 200: 85: $85 \mathrm{~kg} \mathrm{~N}: \mathrm{P}_{2} \mathrm{O}_{5}: \mathrm{K}_{2} \mathrm{O} /$ ha significantly $(\mathrm{P}<0.05)$ increased growth, yield attributes and grain yield over 100: 50: 50 and 150: 65: $65 \mathrm{~kg} \mathrm{~N}$ : $\mathrm{P}_{2} \mathrm{O}_{5}: \mathrm{K}_{2} \mathrm{O} /$ ha and fetched the highest $\mathrm{B}$ : $\mathrm{C}$ ratio (3.14).
\end{abstract}

Keywords: Economics, Fertility level, Planting time, Plant population, Popcorn yield

\section{INTRODUCTION}

In cereals, introduction of high yielding maize is worth exploring for enhancing the food production. The ability of the maize popcorn to grow in different seasons and high productivity of rabi/winter and spring maize give it an added advantage for inclusion in the cropping system as demand for more food production. As the winter maize are gaining popularity among farmers and multinationals because of lower photo respiration losses due to lower night temperatures as well as larger leaf surface for effective photosynthetic activities. Maize is grown throughout the year mainly due to photo-thermo-insensitive character, hence called 'queen of cereal'.

Under such changing climate scenario, maize is considered to be a best alternative to wheat or boro or rabi rice due to its high potential which has opened up a viable alternative. Cultivation during winter is becoming a common practice in peninsular India (Andhra Pradesh, Karnataka and Tamil Nadu), as well as in the north-eastern plains under ensured irrigation condition (Singh et al., 2012). Because of its yield potential as high as 10 to $12 \mathrm{tha}^{-1}$, and further increase in productivity substantially up to $18 \mathrm{tha}^{-1}$ with better management, the winter maize cultivation in increasing not only in Bihar but also in other states (Singh, 1998). Presently, winter maize is being grown in an area of about 1.2 million ha with the grain production of 5.08 million tones, and at an average productivity of $4.00 \mathrm{t}$ $\mathrm{ha}^{-1}$ (DACNET, 2012) in India.

Among different groups or types based on the endosperm of kernels, Pop corn (Zea mays var. everta) is perhaps the most primitive of the surviving race of corn. It is a most popular foodstuff in peri-urban areas in big cities of all over the world and that called the king of nutritious snack food. This corn type is characterized by a very hard, corneous endosperm containing only a small portion of soft starch. Time of sowing is a non monetary input plays significant role in production and productivity of any popcorn (Verma et al. 2012). Optimum plant density is another important factor for high grain yield. Yield can be increased with increased plant density up to a maximum for some maize genotypes grown under a set of particular environmental management conditions and declines when plant density is increased further (Tollenaar et al., 1994). Popcorn is exhaustive popcorn which requires all types of macro and micro nutrients in order to get better growth and exploit yield potential. Among the various nutrients, nitrogen is the principal nutrients which should 
be applied@150 kg N/ha in order to have better harvest (Kong et al., 2008). The efficiency of nitrogen utilization is better in Rabi than in Kharif season, primarily because of better water management and lower leaching losses. With better fertilizer response, it should be possible to substantially reduce the cost of production of every tone of popcorn produced in $R a b i$ season. Keeping in view the economic importance of rabi popcorn, it is now becoming popular as a nontraditional popcorn under irrigated ecosystem. It can be very well accommodated during winter season in the area where planting time of rabi popcorns particularly wheat are much delayed than the normal due to many constraints undergoing the area. In view of the above facts, therefore the present study was planned to evaluate the planting time among different population density at different levels of inorganic sources of fertility levels on growth, yield attributes, yield and economics of popcorn under late sown condition.

\section{MATERIALS AND METHODS}

The field experiment was laid out in split plot design with three replications, assigning in 27 treatment combinations i.e. three sowing dates (15 Dec, $30 \mathrm{Dec}$ and 15 Jan) arranged in main plots and three level of plant population $\left(60000,80000\right.$ and 100,000 plants ha $\left.{ }^{-1}\right)$ in sub plot. Three level of fertility (100:50:50, 150:65:65 and 200:85:85 kg of $\mathrm{N}: \mathrm{P}_{2} \mathrm{O}_{5}: \mathrm{K}_{2} \mathrm{O} \mathrm{ha}^{-1}$ ) apportioned in sub-sub plots at the Research farm, Institute of Agricultural Sciences, BHU, Varanasi (U.P.) during late winter (rabi) seasons of 2009-10 and 2010-11. The soil of experimental field was sandy clay loam in texture with $\mathrm{pH}$ 7.6, $0.35 \%$ organic carbon and low in available nitrogen 183 , 21.02 and $228 \mathrm{~kg} / \mathrm{ha}$ of available phosphorus and potassium, respectively by analyzed soil samples for available $\mathrm{N}$ (Estimated by Alkaline permanganate method, Subbiah and Asija, 1973), $\mathrm{P}_{2} \mathrm{O}_{5}$ (Olsen method, Olsen, S.R. 1954) $\mathrm{K}_{2} \mathrm{O}$ (Flame photometer method, Jackson, 1973) and potassium. Popcorn cultivar "V.L. Amber" was sown by opening $5 \mathrm{~cm}$ deep furrow $60 \mathrm{~cm}$ apart seeds were placed at a distance of $27.8 \mathrm{~cm}, 20.8 \mathrm{~cm}$ and 16.6 $\mathrm{cm}$ to maintain the required plant population of 60,000 , 80,000 and 100,000 plants/ha. The nutrient sources used were, 174.86: $80.44: 83.33 \mathrm{~kg} / \mathrm{ha}$, 270.79:141.30:108.33 kg/ha and 362.47:184.78:141.66 $\mathrm{kg} / \mathrm{ha}$ for Urea: DAP (Di-ammonium phosphate) and MOP (Muriate of potash) to fulfill the 100:50:50, 150:65:65 and 200:85:85 $\mathrm{kg} \mathrm{N}, \mathrm{P}_{2} \mathrm{O}_{5}$ and $\mathrm{K}_{2} \mathrm{O}$ ha ${ }^{-1}$, respectively. The total quantity of $\mathrm{P}_{2} \mathrm{O}_{5}$ requirement of and $\mathrm{K}_{2} \mathrm{O}$ along with $1 / 3 \mathrm{~N}$ (as per treatment) were applied as basal at the time of sowing. A blanket application of zinc sulphate @ $25 \mathrm{~kg} / \mathrm{ha}$ was applied to all the experimental plots as per recommended package of practices. The remaining quantity of $\mathrm{N}$ was top dressed in two equal splits at knee height and tasseling stages. Others compulsory activities viz. intercultural and plant protection measures were applied as need based.
The data were analyzed statistically for comparing the treatment means. Five plants in net plot were randomly selected and tagged for recording the biometric observations at different stages of growth. However, for measuring dry matter accumulation, two plants from the border rows were randomly selected. The observations on growth attributes were recorded at a monthly interval i.e. 30, 60, 90, 120 days after sowing (DAS) and at harvest. Yield attributes and yield were studied before and after harvesting as per investigation required.

Plant height (cm) : Height of the randomly selected and marked five plants was measured at 30 days interval and at harvest. The plant height was measured from the base of the plant to the base of the fully opened top leaf until cob emergence. Later the plant height was measured from the base of the plant to the collar of flag leaf and expressed in centimeters.

Leaf area index (LAI): - was obtained by the following formula (Hunt, 1978).

\section{LAI $=\quad\left(\right.$ Leaf area $\left.\left(\mathrm{cm}^{2}\right)\right) /\left(\right.$ Land area covered by plant $\left(\mathrm{cm}^{2}\right)$}

Dry matter accumulation plant $^{-1}$ (g): The randomly selected five plant at all the stages form border rows in each plot were cut from the ground levels; sun dried and then transfer to a thermostatically controlled dry oven, regulated at temperature of $70^{\circ} \mathrm{C}$ for about 24 hours to obtain constant dry weight. Thereafter, the average dry weight per plant was recorded. Then average dry weight per plant was recorded and reported in $(\mathrm{g})$ plant $^{-1}$.

Popcorn growth rate $\left(\mathrm{g} \mathrm{day}^{-1}\right)$ : Popcorn growth rate (CGR) is the gain in dry matter production on a unit of land in a unit of time. CGR was observed at 30 days interval and at harvest (Watson, 1958).

$$
\operatorname{CGR}\left(\text { g days }^{-1}\right)=\frac{w_{2}-w_{1}}{t_{2}-t_{1}}
$$

Where

$$
\begin{aligned}
& \mathrm{W}_{2}=\text { dry weight per unit area at } \mathrm{t}_{2}, \\
& \mathrm{~W}_{1}=\text { dry weight per unit area at } \mathrm{t}_{1}, \\
& \mathrm{t}_{1}=\text { first sampling, and } \\
& \mathrm{t}_{2}=\text { second sampling. }
\end{aligned}
$$

Kernels row $^{-1}$ : The number of kernels counted in rows of 5 cobs averaged to get the number of kernels per row.

Shelling percentage: The weight of five cobs was recorded and then they were shelled. The grain so obtained from the cobs were weighed and based on these two observations the shelling percentage was calculated as per the following formula.

Shelling percentage $=\left(\right.$ Weight of grains $\operatorname{cob}^{-1} /$ Total weight of cob) $\times 100$

Grain yield $\left(\mathbf{q} \mathbf{h a}^{-1}\right)$ : The cobs were stripped off their husk and air dried for one week and then these were shelled separately. The shelled grains were cleaned and sun dried to obtain a constant weight. This gave the yield in $\mathrm{kg} \mathrm{plot}^{-1}$ and then it was computed in to yield 
in quintals hectare ${ }^{-1}$ by multiplying with a conversion factor of 11.11 .

Stover yield (q ha $\left.\mathbf{~ h}^{-1}\right)$ : The plants of each plot were cut from ground level after removal of the cobs. The stover was allowed to sun dried to obtain a constant weight which gave the stover yield in $\mathrm{kg}_{\text {plot }}{ }^{-1}$ and then it was computed into quintals hectare ${ }^{-1}$ by multiplying with a conversion factor of 11.11 .

Economics : The cost of cultivation, gross return, net returns and benefit cost ratio, of different treatments were worked out on the basis of prevailing market prices. Power and labour for different operations i.e. ploughing, harrowing, sowing, weeding, harvesting, shelling etc. were calculated $\mathrm{ha}^{-1}$ as per normal rates prevalent at the research farm, B.H.U. Varanasi. The cost of fertilizers and seeds were considered as market price. Net return (Rs. ha ${ }^{-1}$ ) and benefit cost ratio, were computed with the help of following.

Gross return (Rs. ha $\left.\mathbf{~}^{-1}\right)$ : The yield of winter popcorn was converted into gross return in Rs. $\mathrm{ha}^{-1}$ on the basis of current price of the produce.

Net returns (Rs. ha $\left.{ }^{-1}\right)$ : Net Return (Rs.) = Gross return $\left(\right.$ Rs. ha $\left.{ }^{-1}\right)-$ Cost of cultivation (Rs. ha $\left.{ }^{-1}\right)$

Output input ratio/Benefit cost ratio (B: C) or BCR

Benefit cost ratio $=\frac{\text { Net return }\left(\text { Rs. ha }{ }^{-1}\right)}{\text { Total cost of cultivation }_{\left(\text {Rs. } \mathrm{ha}^{-1}\right)}}$

Statistical analysis : To test the significance, the experimental data collected on various aspects of the investigation on maize and soil were statistically analyzed with the procedure described by Cochran \& Cox (1967) and adopted by Cheema and Singh (1991) in statistical package CPCS-1. All the comparisons were made at $5 \%$ level of significance.

\section{RESULTS AND DISCUSSION}

Planting time: During the present study, different date of planting significantly $(\mathrm{P}<0.05)$ influenced the growth and yield attributing characters (kernel/row and kernels/cob) and $15^{\text {th }}$ Dec recorded maximum plant height, leaf area index, dry matter production plant ${ }^{-1}$, and popcorn growth rate than $15^{\text {th }}$ Jan. However, the plant height of $30^{\text {th }}$ Dec was remained at par over $15^{\text {th }}$ Jan and closely followed $15^{\text {th }}$ Dec during the study (Table 1). The comparatively higher rate of photosynthesis and low rate of thermo-photo effect caused higher conservation of photosynthates, which in turn concomitantly with favourable climatic conditions provided more height to the popcorn planted on $15^{\text {th }}$ December. The early planting significantly increased the plant height is in agreement with the results of Jafari (2010) on forage millet and Moosavi et al., (2012) on forage corn. As a result a significant $(\mathrm{P}<0.05)$ improvement in the plant height accounted maximum value of leaf area index and dry matter production in popcorn growth of popcorn. On the contrary, the popcorn planted on $30^{\text {th }}$ December and $15^{\text {th }}$ January experienced the effect of uncongenial low and high temperature coincided with the growth and reproductive phases of the popcorn, respectively and resulted in untimely and forced maturity realized lower LAI and popcorn growth rate in study. Similar trend of effect has also been advocated by Sutaliya and Singh (2005) in experienced on winter corn sown on $15^{\text {th }}$ Dec $\& 30^{\text {th }}$ Dec at Varanasi.

Moreover, the yield attributes such as kernel per row and kernel per cob was significantly increased with planting on $15^{\text {th }}$ Dec planting over $30^{\text {th }}$ Dec and $15^{\text {th }}$ Jan and it could be due to better growth of popcorn.

Table 1. Growth and yield attributing characters of winter popcorn as influenced by planting time, plant population and fertility levels (Pooled data).

\begin{tabular}{|c|c|c|c|c|c|c|c|}
\hline Treatment & $\begin{array}{c}\text { Plant height } \\
\text { (cm) }\end{array}$ & $\begin{array}{c}\text { Leaf } \\
\text { Area } \\
\text { Index }\end{array}$ & $\begin{array}{c}\text { Plant dry } \\
\text { wt. } \\
\text { (g/plant) }\end{array}$ & $\begin{array}{c}\text { Popcorn } \\
\text { growth rate } \\
\text { (g/unit/time) }\end{array}$ & $\begin{array}{l}\text { Kernel / } \\
\text { row }\end{array}$ & $\begin{array}{c}\text { Kernel / } \\
\text { cob }\end{array}$ & $\begin{array}{c}\text { Shelling } \\
\text { percentage }\end{array}$ \\
\hline \multicolumn{8}{|l|}{ Planting time } \\
\hline $15^{\text {th }}$ December & 169.90 & 3.87 & 224.69 & 2.64 & 33.35 & 372.88 & 76.69 \\
\hline $30^{\text {th }}$ December & 163.15 & 3.41 & 211.98 & 2.10 & 30.55 & 329.43 & 71.65 \\
\hline $15^{\text {th }}$ January & 155.85 & 2.74 & 203.97 & 1.53 & 27.40 & 273.12 & 66.68 \\
\hline S.Em \pm & 3.15 & 0.09 & 2.61 & 0.02 & 0.60 & 9.06 & 1.06 \\
\hline C.D. $(\mathrm{P}=0.05)$ & 9.45 & 0.25 & 7.83 & 0.07 & 1.85 & 27.17 & 3.17 \\
\hline \multicolumn{8}{|c|}{ Plant population (Plant/ha) } \\
\hline 60,000 & 158.60 & 3.30 & 203.30 & 2.08 & 29.70 & 350.23 & 73.86 \\
\hline 80,000 & 166.45 & 4.19 & 220.95 & 2.26 & 31.80 & 380.48 & 74.92 \\
\hline 100,000 & 170.90 & 2.53 & 211.89 & 2.17 & 27.05 & 321.22 & 72.74 \\
\hline S.Em \pm & 3.15 & 0.09 & 2.61 & 0.02 & 0.60 & 9.06 & 1.07 \\
\hline C.D. $(\mathrm{P}=0.05)$ & 9.45 & 0.25 & 7.83 & 0.07 & 1.07 & 27.17 & NS \\
\hline \multicolumn{8}{|c|}{ Fertility level $\left(\mathrm{N}, \mathrm{P}_{2} \mathrm{O}_{5}\right.$ and $\left.\mathrm{K}_{2} \mathrm{O} / \mathrm{ha}\right)$} \\
\hline $100: 50: 50$ & 157.80 & 3.09 & 185.23 & 1.45 & 26.50 & 323.42 & 68.69 \\
\hline 150: $65: 65$ & 165.45 & 3.43 & 214.20 & 2.04 & 29.95 & 362.60 & 72.82 \\
\hline 200: $85: 85$ & 173.15 & 3.75 & 235.71 & 2.78 & 33.25 & 401.92 & 77.52 \\
\hline S.Em \pm & 2.40 & 0.08 & 1.37 & 0.09 & 0.60 & 12.60 & 0.97 \\
\hline C.D. $(\mathrm{P}=0.05)$ & 6.85 & 0.24 & 3.92 & 0.24 & 1.80 & 36.13 & 2.79 \\
\hline
\end{tabular}


Table 2. Yields and economics of winter popcorn as influenced by planting time, plant population density and fertility levels (Pooled data of two years).

\begin{tabular}{|c|c|c|c|c|c|c|}
\hline Treatments & $\begin{array}{c}\text { Grain yield } \\
(\mathrm{q} / \mathrm{ha})\end{array}$ & $\begin{array}{c}\text { Stover yield } \\
(\mathrm{q} / \mathrm{ha})\end{array}$ & $\begin{array}{c}\text { Cost of culti- } \\
\text { vation }\end{array}$ & $\begin{array}{c}\text { Gross return } \\
\text { (Rs/ha) }\end{array}$ & $\begin{array}{c}\text { Net return } \\
\text { (Rs/ ha) }\end{array}$ & $\begin{array}{l}\text { B: } C \\
\text { ratio }\end{array}$ \\
\hline \multicolumn{7}{|l|}{ Planting time } \\
\hline $15^{\text {th }}$ December & 33.76 & 51.41 & 35374 & 168800 & 134456 & 3.78 \\
\hline $30^{\text {th }}$ December & 28.57 & 47.61 & 37249 & 142850 & 105601 & 2.84 \\
\hline $15^{\text {th }}$ January & 25.34 & 44.44 & 39318 & 126700 & 87382 & 2.22 \\
\hline S.Em \pm & 0.65 & 0.89 & --- & 3117 & 3109 & 0.08 \\
\hline C.D. $(\mathrm{P}=0.05)$ & 1.94 & 2.67 & --- & 9345 & 9321 & 0.23 \\
\hline \multicolumn{7}{|c|}{ Plant population (Plants/ha) } \\
\hline 60,000 & 26.76 & 45.755 & 35353 & 133800 & 98447 & 2.78 \\
\hline 80,000 & 32.61 & 47.955 & 37598 & 163050 & 125452 & 3.34 \\
\hline 100,000 & 29.29 & 49.74 & 38991 & 146450 & 107459 & 2.76 \\
\hline S.Em \pm & 0.65 & 0.89 & --- & 3117.3 & 3109 & 0.06 \\
\hline C.D. $(\mathrm{P}=0.05)$ & 1.94 & 2.67 & --- & 9345 & 9321 & 0.19 \\
\hline \multicolumn{7}{|c|}{ Fertility level $\left(\mathrm{N}, \mathrm{P}_{2} \mathrm{O}_{5}\right.$ and $\left.\mathrm{K}_{2} \mathrm{O} / \mathrm{ha}\right)$} \\
\hline 100: $50: 50$ & 25.69 & 43.825 & 35283 & 128450 & 93167 & 2.64 \\
\hline 150: $65: 65$ & 30.53 & 47.79 & 37228 & 152650 & 115422 & 3.10 \\
\hline 200: $85: 85$ & 34.94 & 51.835 & 39430 & 174700 & 135270 & 3.43 \\
\hline S.Em \pm & 0.59 & 0.675 & --- & 2856 & 2862 & 0.08 \\
\hline C.D. $(\mathrm{P}=0.05)$ & 1.70 & 1.94 & --- & 8193 & 8207 & 0.23 \\
\hline
\end{tabular}

Similarly, the grain yield was also increased significantly with the sowing of popcorn on $15^{\text {th }}$ December that late and very late sown popcorn (Table 2). Kolawole et al., (2009) reported that these enhancement might be due to the better translocation system in popcorn plant enhance the production of yield due to the fact that good photosynthates accumulated in leaves and its transfer to economic part like grains, cobs etc. a fact the higher rate of photosynthesis resulted highest yield attributes. Further, the planting at $15^{\text {th }} \mathrm{Dec}$ also fetched highest net return and benefit: cost ratio (3.83) followed by $30^{\text {th }} \mathrm{Dec}$ and $15^{\text {th }}$ Jan due to higher grain yield.

Plant population: During the present study, different plant population had significant variations in plant height, LAI, dry matter production and popcorn growth rate during study (Table 1 ). The population of 80,000 plants/ha registered significantly $(\mathrm{P}<0.05)$ more LAI, dry matter production and popcorn growth rate over 60,000 and 100,000 plants/ha. While, the value of popcorn height was remained at par with 100,000 plants and closed to 60,000 plants/ha. Increased plant height at high population density $(100,000$ popcorn plants/ha) has not contributed to increased dry matter. This clearly indicates that increase in number of plants per unit area beyond optimum level certainly reduced the amount of light availability to the individual corn, especially, to lower leaves due to shading. As the intensity of shading increases due to high population densities, the plant tends to grow taller. Such increase in height of the sweet corn plant at high population densities (111111 plants/ha) was reported by Ashok Kumar (2009) during experiment at New Delhi. Chandankar et al. (2005) from an experiment conducted on clay soils of Akola reported increase in plant height of maize hybrid (Pro Agro 4640) with higher plant density (111111 plants/ha) than with lower planting den- sity (83333 plants/ha). Further, dry matter production increased with increasing popcorn plant density from 60,000 to 80,000 plants/ha due to more leaf area/unit as the canopy expanded more rapidly resulted more intercepted radiation produced more dry matter (Singh and Choudhary, 2008). Further increase in plant population up to 100,000 plants/ha progressively dry matter decreased as the number of plants increases in a given area because the growth of individual plant is reduced reported by Hamidia et al., (2010).

The yield attributes viz., kernel per row, kernel per cob and grain yield of popcorn during present study were significantly $(\mathrm{P}<0.05)$ influenced by plant densities (Table 1 and 2$)$. The significant $(\mathrm{P}<0.05)$ increase in kernel number/row and kernel /cob noticed at a population of 80,000 plants/ha (31.59) compared to 100,000 plants and 60,000 plants/ha. Abuzar et al. (2011) reported in maize at plant population of 60,000 plants/ha during July than $80,000,100,000$ and 140000 plants/ ha. The reason might be attributed to the availability of better resources in low to medium plant density. In high plant density, the number of individual plants per area is increased beyond the optimum plant density, there are severe consequences that are detrimental to ear ontogeny that result in barrenness (Sangoi. 2001). In terms of yield, during present study grain yield increased significantly $(\mathrm{P}<0.05)$ with increases in plant densities and recorded maximum up to 80,000 plants $\mathrm{ha}^{-1}(32.61 \mathrm{q} / \mathrm{ha})$, but decreased at the highest plant density $(100,000$ popcorn plants/ha). The gross return and net return of popcorn was also maximum with 80,000 plants/ha and fetched highest benefit cost ratio (3.34) compared with 100,000 plants/ha and lowest being with 60,000 plants/ha in density. Sankaran et al., (2005) opined that application of plant population of 83333 maize plants/ha obtaining the maximum produc- 
tivity and $\mathrm{B}, \mathrm{C}$ ratio in maize.

Effect of fertility levels: During the present study, fertility level had marked effect on all the growth attributing characters (plant height, leaf area index and plant dry weight) of popcorn. Increasing fertility levels significantly $(\mathrm{P}<0.05)$ affected the plant height and it was maximum at $200,85,85 \mathrm{~kg}$ of $\mathrm{N}, \mathrm{P}_{2} \mathrm{O}_{5}$ and $\mathrm{K}_{2} \mathrm{O}$ / ha of fertility level of popcorn growth. The higher level of fertility accomplished the requirement of balanced popcorn nutrition and caused rapid division and elongation of cells that resulted in improvement in plant height. Similar effect of fertility levels on plant height were reported by Rafiq et al., (2010) in autumn planted maize. Each increase in the level of fertility got a balanced addition in the amount of nitrogen, phosphorous and potassium, which caused vital improvement in the popcorn growth, thereby, achieved more number of leaf area index. The leaf area index and dry matter production were recorded highest with maximum fertility level i.e. $200,85,85 \mathrm{~kg}$ over $100,50,50$ $\mathrm{kg}$ during present study (Table 1). The greater plant height at increased fertility level leaded more leaf area index, also advocated by Bhatt, (2012) in sweet corn. The number of green leaves declined after 90 days of sowing due to corresponding reduction in leaf area distribution over land area and reached to its minimum at harvest by advance stages of popcorn growth.

The table 1 and 2 showed that the yield attributing characters of popcorn such as kernel per row, kernel per cob and grain yield of popcorn was significantly $(\mathrm{P}<0.05)$ more with 200: 85: $85 \mathrm{~kg} \mathrm{~N}: \mathrm{P}_{2} \mathrm{O}_{5}: \mathrm{K}_{2} \mathrm{O} / \mathrm{ha}$ over 150: 65: $65 \mathrm{~kg}$ and 100: 50: $50 \mathrm{~kg} \mathrm{~N}: \mathrm{P}_{2} \mathrm{O}_{5}: \mathrm{K}_{2} \mathrm{O} /$ ha during present study. This may probably be attributed to NPK being part of the essential nutrients required for the promotion of the meristematic and physiological activities such as plant leaf spread, root development, plant dry matter production etc leading to an efficient absorption and translocation of water and nutrients, interception of solar radiation and assimilation of carbon dioxide. These activities promote higher photosynthetic activities leading to the production of enough assimilate for subsequent translocation to various sink and hence the production of higher yield and yield component of popcorn. Namakha et al. (2008) also found that it may be due to optimum and regular supply of nitrogen nutrient to plant from soil during growth period by more assimilation rate and it is integral part of protein the building blocks of maize plant. These led to the highest benefit cost ratio i.e. 3.43 with 200: 85: $85 \mathrm{~kg}$ of $\mathrm{N}: \mathrm{P}_{2} \mathrm{O}_{5}: \mathrm{K}_{2} \mathrm{O} /$ ha fertility levels respectively. Sankaran et al., (2005) opined that enhancement in fertilizer application to the tune of 2550 per cent recommended dose of $\mathrm{N}(203 \mathrm{~kg} / \mathrm{ha})$ increased the gross, net and $\mathrm{B}, \mathrm{C}$ ratio in maize.

\section{Conclusion}

During the present study. it was revealed that sown on $15^{\text {th }}$ December with planting of 80,000 plants/ha along with application of $200,85,85 \mathrm{~kg}$ of $\mathrm{N}, \mathrm{P}_{2} \mathrm{O}_{5}$ and $\mathrm{K}_{2} \mathrm{O}$ /ha significantly $(\mathrm{P}<0.05)$ influenced growth parameters, yield components, yield, net return and $\mathrm{B}$ : $\mathrm{C}$ ratio over those sown on rest date of sowing along with plant population as well as fertilizer levels. It can be gown upto $15^{\text {th }}$ December with above given population and fertilizer levels instead of wheat in rice- wheat cropping system by farmers in based of commercial view.

\section{ACKNOWLEDGEMENTS}

The authors are thankful to the Head of the department of Agronomy BHU, Varanasi, for encouraging such research and providing necessary facilities for the successful completion of research work.

\section{REFERENCES}

Abuzar, M. R., Sadozai G. U., Baloch, M. S., Baloch, A. A., Shah, I., Javaid, H. T. and Hussain, N. (2011). Effect of plant population densities on yield of maize. J. Ani. Plant Sci., 21(4): 692-695.

Bhatt, P.S. (2012). Response of sweet corn hybrid to varying plant densities and nitrogen levels. African J. of Agricl. Res., 7 (46):6158-6166.

Chandankar, M. M., Ghanbahadur, M. R. and Shinde, V. S. (2005). Yield and economics of maize as influenced by FYM, N, P, K and plant density. Ann plant Physiol. 19 (2): 172-174.

Cheema, H.S. and Singh, B. (1991). Software Statistical Package CPCS-1. Department of Statistics, Punjab Agricultural University, Ludhiana, India.

Cochran, W.G. and Cox, G.M. (1967). Experimental Designs. Asia Publishing House New Delhi.

DACNET. (2012). Rabi maize, Opportunities and challenges, Directorate of Maize Research, Indian Council of Agricultural Research, Pusa Campus, New Delhi, 110012, 1-25.

Hamidia, A., Khodabhandehb, N. and Mohanndynasabe, A.D. (2010). Plant density and nitrogen effects on some traits of maize (Zea mays L.). Plant Ecophysiol. 2:47-52.

Hunt, R. (1978). Plant Growth Analysis. Studues in Biology No. 96. Edward Arnold, London.

Jackson, M.L. (1973). Soil chemical analysis, Prentice-Hall of India Pvt. Ltd., New Delhi.

Jafari, M. (2010). Effect of planting date, irrigation intervals and nitrogen rates on morphological and yield of forage millet. M.Sc. Thesis on Agriculture, Islamic Azad University, Birjand Branch, Iran, pp. 113.

Kolawole, E. and Samson, U. (2009). Growth and Yield of Maize as Influenced by Sowing Date and Poultry Manure Application. Not. Bot. Hort. Agrobot. Cluj, 37 (1): 199-203.

Kong, W. D., Zhu, Y. G., Fu, B. J., Han, X. Z., Zhang, L. and J. Z. He., (2008). Effect of long-term application of chemical Fertilizers on microbial biomass and functional diversity of a black soil. Pedosphere. 18(6): 801-808.

Kumar, Ashok (2009). Production potential and nitrogen use efficiency of sweet corn (Zea mays) as influenced by different planting densities and nitrogen levels. Indian J. of Agric. Sci., 79(5): 351-55. 
Moosavi ,S. G. Seghatoleslami, M. J. and Moazeni, A. (2012). Effect of planting date and plant density on morphological traits, LAI and forage corn (Sc. 370) yield in second cultivation. Intl Res J of Applied and Basic Scie. 3 (1), 57-63. Available online at http://www. irjabs.com.

Muhammad A. Rafiq, Asghar Ali, Muhammad Asghar Malik ${ }^{1}$ and Mumtaz Hussain (2010). Effect of fertilizer levels and plant densities on yield and protein contents of autumn planted maize, Pak. J. Agri. Sci., 47(3): 201-208.

Namakha, A., Bubakar, I. U., Sadik, I. A., Sharifai, A. I. and Hassas, A. H. (2008). Effect of sowing date and nitrogen level on yield and yield components of two extra early maize varieties (Zea mays L.) in Sudan Savanna of Nigeria, ARPN J. of Agr. and Bio. Sci. 3 (2): 15.

Olsen, S.R. (1954). Estimation of available phosphorus in soil by extraction with sodium bi-carbonate, U.S.D.A. Circ., 939.

Sangoi, L. (2001). Understanding plant density effects on maize growth and development: an important issue to maximize grain yield. Ciencia Rural, 31 (1): 159-168.

Sankaran, N., Meena, S. and Sakthivel, N. (2005). Input management in maize. Madras Agril. J. 92(7-9): 464-68.

Singh, D. and Choudhary, J. (2008). Effect of plant population and fertilizer levels on yield and economics of pop corn. Indian J. Plant Sci., 78(4): 370-371.

Singh, N., Rajendran, R., Shekhar, M. A., Jat, Kumar, S.L.
R. \& Kumar, R. S. (2012). Rabi maize, an Opportunities \& Challenges, Directorate of Maize Research, (ICAR), Pusa Campus, New Delhi -110 012 (India).

Singh, S.B. (1998). Production of specialized maize. Indian Fmg. 48 (1): 74-75.

Subbiah, B.V. and Asija, G.L. (1973). A rapid procedure for estimation of available nitrogen in soils, Current sciences, 28(8): 259-260.

Sutaliya, R. and Singh, R.N. (2005). Effect of planting time, fertility level and phosphate-solubilizing bacteria on growth, yield and yield attributes of winter maize (Zea mays) under rice (Oryza sativa)-maize popcornping system. Indian J. of Agron. 50(3): 173-175.

Tollenaar, M., McCullough, D.E. and Dwyer, L.M. (1994). Physiological basis of the genetic improvement of field crops.(Ed. G.A.Slafe) Marcel and Dekker Inc., New York, 183-236.

Verma, N. K., Pandey, B. K., Singh U. P. and Lodhi, M. D. (2012). Effect of sowing dates in relation to integrated nitrogen management on growth, yield and quality of rabi maize (zea mays 1.). J. of Animal \& Plant Sciences, 22(2): 324-329.

Watson, D. J. (1958). Physiological basis of variation in yield. Adv. Agron., 4: 31-34. 